\title{
CONSIDERAṬII PRIVIND DREPTUL CONSUMATORULUI DE RAMBURSARE ANTICIPATĂ ȘI SANCTIIUNILE APLICABILE CREDITORILOR PROFESIONIȘTI ÎN CONTRACTELE DE CREDIT
}

\author{
DOI:10.24193/SUBBiur.62(2017).4.2 \\ Published Online: 2017-12-20 \\ Published Print: 2017-12-30
}

Juanita GOICOVICI*

\begin{abstract}
Remarks on the Consumer's Right to Early Repayment and the Injunctions Applicable to Professional Creditors in Credit Agreements. The article focuses on certain essential elements of the consumers' right to early repayment; as an empowering prerogative based on which the consumer is entitled to full or partial anticipated discharge of the payment obligations under the credit agreements. While the problematic of unfair terms is frequently focused on; in credit scoring literature; early repayment rights have received much less attention; despite a higher rate of litigious situations related to the clauses fixing the amount of the creditors' compensation. On one hand; the article points out the consumer's entitlement to a reduction in the total cost of the credit; consisting of the interest and the costs attached to additional services. Prepayment of the loan by the borrower is often the result of an optional refinancing on lower interest rates; as an embedded option cost that results in a lower total cost of the credit. On the other hand, there is substantial heterogeneity in the modalities of establishing the minimum and maximum amount for creditors' compensation. In the event of early repayment of the credit; the professional/creditor is entitled to fair and objectively justified compensation for possible costs directly linked to early repayment of credit provided that the early repayment falls within a period for which the borrowing rate is fixed. The second part of the study deals with the consumer's right to discharge fully or partially the obligations under a credit agreement; at any time; unconditionally of the number of rates already paid or the total value of the early payments. Third; the article encompasses the problematic of the mandatory legal provisions ceiling the professionals' right to compensation; which may not exceed $1 \%$ of the amount of credit repaid in advance; if the period of time between the early repayment and the agreed termination of the credit agreement exceeds one year. According to the mandatory legal provisions; if the contractual period does not exceed one year; the creditor's compensation for early repayment may not exceed 0;5 \% of the amount of credit on anticipated repayment. The fourth part of the observations is allocated to the study of the cases in which the professionals' compensation for early repayment may not be claimed: (i) if the repayment has been made under an insurance contract intended to provide a credit repayment guarantee; (ii) in the case of overdraft facilities; or (iii) if the repayment falls within a period for which the parties have established a variable borrowing rate. Finally; the legal injunctions which may be enforced upon the professional creditor for the breach of contractual duties such as the duty of
\end{abstract}


transparency are also discussed. Nonetheless; the article argues that the creditor's right to fair compensation for early repayment does not include a percentage of the costs of ancillary services and that the legal ceiling of the early repayment compensation must be centered on the value of the regular interest rate. Thus; the amount of the early repayment compensation would be connected to the regular interest rate; excluding the annual total cost of the credit/the payments for ancillary services.

Keywords : loans; right to early repayment; consumer; right to compensation; injunctions.

Mots-clé : contrats de crédit ; droit de remboursement anticipé ; consommateur ; sommes compensatoires; sanctions complementaires.

Cuvinte-cheie : contract de credit; drept de rambursare anticipată; consumatori; compensaţie de rambursare; sançiuni complementare.

\section{Observaţii introductive}

\subsection{Calul troian al răspunderii civile a creditorilor profesioniști - obligația bancară de transparență}

Un element esențial pentru protejarea intereselor legitime ale consumatorilor îl constituie cerința de a asigura un nivel ridicat de corectitudine; onestitate și profesionalism în materia formării și executării contractelor de credit; consumatorii trebuind totodată să primească informații personalizate în timp util înainte de încheierea contractului de credit; care să le permită să analizeze și să compare caracteristicile produselor de creditare. Pentru a asigura un nivel cât mai ridicat de transparență și a preveni abuzurile care pot decurge din stabilirea compensației creditorilor pentru rambursare anticipată; aceste obligații ar trebui să includă informații corecte cu privire la modalitatea de calcul și plafoanele aplicabile compensațiilor percepute de creditorul bancar; avându-se în vedere cerințele de diligență profesională. Transparența cu care creditorii bancari anunță în etapa formării contractului plafoanele și modalitățile de calcul ale compensației de rambursare anticipată poate reprezenta un factor stimulator al competiției inter-bancare ${ }^{1}$ și un factor de reducere a costului total al creditării pe piața inter-bancară; precum și un catalizator al preluării cotelor de clientelă; pornind de la prezumția că debitorii consumatori tind să opteze pentru produse de creditare al căror cost final; incluzând compensațiile datorate creditorului în caz de rambursare anticipată; este transparent afișat. Creditorul bancar și; după caz; intermediarul de credite au obligația de a furniza consumatorului; pe baza clauzelor și a condițiilor de creditare specifice; informațiile care să îi permită consumatorului să compare mai multe oferte pentru a putea lua o decizie avizată cu privire la încheierea unui contract de credit; inclusiv din perspectiva cuantumului compensației percepute de respectivul creditor pentru rambursarea anticipată a creditului. 


\subsection{Scurt expozeu al problematicii. Dreptul consumatorului de rambursare anticipată; ca drept potestativ}

Dreptul consumatorului de rambursare anticipată a sumelor împrumutate în baza contractelor de credit este considerat a fi un drept esențial din perspectiva dispozițiilor Directivei 2014/17/UE a Parlamentului European și a Consiliului privind contractele de credit oferite consumatorilor pentru bunuri imobile rezidențiale și de modificare a Directivelor 2008/48/CE și 2013/36/UE și a Regulamentului (UE) nr. 1093/2010; transpusă în dreptul intern prin O.U.G. nr. 52/2016 privind contractele de credit oferite consumatorilor pentru bunuri imobile; precum și pentru modificarea și completarea O.U.G. nr. 50/2010 privind contractele de credit pentru consumatori. Aprecierea caracterului potestativ al dreptului consumatorului de rambursare anticipate este importantă este importantă nu numai prin prisma consecinţelor practice pe care potestativitatea le imprimă exerciţiului acestui drept; ci şi pentru examinarea cerinţelor care ar condiţiona exerciţiul dreptului menţionat. Argumentele de ordin logic; precum şi fundamentele juridice pentru acest drept al consumatorului debitor sunt oferite de înseşi principiile generale ale dreptului contractual civil. Debutând cu observaţia că obligaţia principală care incumbă debitorului în contractul de credit este aceea de a rambursa capitalul împrumutat; creditorul care refuză primirea plăţii integrale a creanţei aflându-se în culpă; se poate acredita ideea existenţei unui drept potestativ al debitorului de a opta pentru rambursarea totală sau parţială; înainte de scadenţă; a sumelor datorate în baza convenţiei de împrumut. Particularităţile exerciţiului dreptului de rambursare anticipată; ca şi dificultăţile practice legate de efectele juridice conexe decurg din stipularea termenului contractual de rambursare; în cazul creditelor pe durată determinată; în beneficiul ambelor părţi; atât al creditorului; cât şi al debitorului consumator.

Problematica efectelor juridice ale exerciţiului dreptului consumatorului de rambursare anticipată este circumscrisă de observaţia că; în mod uzual; în contractele civile şi comerciale; termenul şi condiţia - ca modalităţi (suspensive/ extinctive) afectând efectele actului juridic pot fi stipulate fie în interesul univoc al uneia din părţi; fie în interesul fiecăreia dintre părţi. în primul caz; partea în beneficiul căreia a fost stipulat termenul sau a fost prevăzută condiţia suspensivă sau rezolutorie poate renunţa la beneficiul termenului/condiţiei; respectiva parte având un drept potestativ de a se prevala de beneficiul termenului/condiţiei; fără ca celălalt contractant să îi poată contracara sau contesta decizia luată. După cum s-a subliniat în literatura de specialitate ${ }^{2}$; dacă în beneficiul creditorului a fost stipulat un termen suspensiv; debitorul nu-I poate sili pe creditor să facă uz de beneficiul termenului.

În contractele de credit pe durată determinată încheiate cu consumatorii; termenul final de rambursare nu este stipulat în interesul exclusiv al consumatorului; încât acesta să poată renunţa la beneficiul termenului printr-o rambursare anticipată fără costuri; în baza exerciţiului non-oneros al unui drept de plată integrală a capitalului împrumutat. Dreptul consumatorului de rambursare anticipată subzistă; întrucât este vorba despre executarea obligaţiei principale a debitorului; însă întrucât acesta contracarează efectele termenului contractual; exerciţiul dreptului său va fi unul oneros; creditorul fiind îndreptăţit la o compensaţie obiectivă; după cum rezultă din textul art. 67 din O.U.G. nr. 50/2010 privind contractele de credit încheiate cu consumatorii; modificată prin O.U.G. nr. 52/2016 privind contractele de credit oferite 
consumatorilor pentru bunuri imobile; precum și pentru modificarea și completarea O.U.G. nr. 50/2010 privind contractele de credit pentru consumatori ${ }^{3}$.

Ne propunem; în paragrafele care urmează; să abordăm problematica obligaţiei profesioniştilor de transparenţă privind calculul compensaţiei de rambursare anticipată; respectiv aspectele practice legate de interzicerea compensaţiei de rambursare anticipată în ipotezele enumerate în art. 68 din O.U.G. nr 50/2010 privind contractele de credit încheiate cu consumatorii. $\mathrm{O}$ a treia parte a analizei este centrată pe aplicabiliatea dispoziţiilor legale imperative de plafonare a compensaţiei de rambursare anticipată; pentru ca cea de-a patra parte a consideraţiilor de mai jos să fie alocată nulitatăţii clauzelor privind renunţarea consumatorilor la dreptul de rambursare anticipată. În fine; ultima parte a analizei propuse vizează sancţiunile aplicabile în situaţia încolcării de către propesionişti a obligaţiilor specifice în materia contractelor de credit încheiate cu consumatorii; inclusiv din perspectiva sancţiunilor complementare incidente în asemenea cazuri.

\subsection{Ambivalenţa interesului ocrotit. Stipularea termenului de plată atât în interesul debitorului; cât şi în interesul creditorului}

În cazul convenţiilor de credit acordat cu dobândă pe durată determinată; termenul de rambursare este stipulat; pe de o parte; în interesul debitorului; căruia nu i se poate solicita anticipat plata capitalului împrumutat şi; pe de altă parte; în mod evident; termenul este stipulat de asemenea în interesul creditorului profesionist; întrucât acesta emite previziuni în legătură cu fructele civile produse de capitalul împrumutat în intervalul prevăzut în contract. După cum subliniază profesorul Jean-Denis Pellier ${ }^{4}$; creditorul profesionist nu poate bloca opţiunea consumatorului debitor de a-şi executa anticipat obligaţia de restituire a capitalului împrumutat; însă în situaţiile în care creditul a fost contractat pe perioadă determinată în mod oneros (capital producător de fructe civile); creditorul este îndreptăţit să primească o compensaţie de rambursare anticipată înscrisă în limitele legale.

De remarcat că; fiind vorba despre executarea înainte de expirarea termenului contractual a obligaţiei principale a debitorului de rambursare a împrumutului; având în vedere că debitorul nu poate fi silit să amâne executarea unei obligaţii de plată care îi revine; consumatorul poate lua decizia de rambursare anticipată în orice moment. Exerciţiul dreptului de rambursare anticipată va avea loc fără ca creditorul să poată condiţiona executarea anticipată nici stipulând că ar fi necesar un anumit număr de rate achitate; nici stipulând că executarea anticipată nu ar putea fi parţială (referindu-se la o parte din capitalul împrumutat). Consumatorului debitor nu i se poate impune o sumă minimă de plată anticipată; acesta fiind liber să execute şi parţial obligaţia sa de rambursare care depăşeşte valoarea ratei scadente. Evident că; în acest caz; debitorul va primi un nou grafic de rambursare; care să ţină cont de achitarea anticipată a unei părţi din capitalul împrumutat.

Astfel cum s-a precizat în literatura de specialitate ${ }^{5}$; limita maximă secundară; aplicabilă valorii compensaţiei de rambursare anticipată este stabilită pornind de la valoarea ratei fixe a dobânzii pe care ar fi perceput-o creditorul în intervalul de timp pentru care are loc plata anticipată; într-un cuantum pe care compensaţia de rambursare anticipată nu în 
poate depăşi. Rambursarea anticipată a împrumutului permite consumatorului să obţină o reducere a costului total al creditului; această reducere constând în dobânda şi costurile aferente perioadei dintre data rambursării anticipate şi data prevăzută pentru încetarea contractului de credit ${ }^{6}$. Se cuvine menţionat faptul că încălcarea acestor dispoziţii legale de către creditorul profesionist reprezintă contravenţie şi se sancţionează cu amenda contravenţională; conform art. 86 din O.U.G. nr. 50/2010 privind contractele de credit încheiate între profesionişti şi consumatori; cu modificările şi completările ulterioare.

\section{Obligaţia profesioniştilor de transparenţă privind calculul compensaţiei de rambursare anticipată. Schimbări palpabile sau implicare secvenţială?}

După cum a fost subliniat în literatura de specialitate alocată temei; obligaţia profesioniştilor de transparenţă privind calculul compensaţiei de rambursare anticipată se referă la îndatorirea creditorului profesionist de informa consumatorul încă din faza precontractuală; asupra modalităţii de calcul al compensaţiei; modalitate care trebuie să fie clară; transparentă şi verificabilă pe baza unor elemente obiective. În contractele de credit pe durată determinată cu o rată fixă a dobânzii aplicabile; termenul final de rambursare nu este stipulat în interesul exclusiv al consumatorului; astfel încât acesta nu poate renunţa gratuit la beneficiul termenului printr-o rambursare anticipată; întrucât termenul este prevăzut şi în interesul creditorului bancar; debitorul datorează o compensaţie echitabilă pentru rambursarea anticipată; integrală sau parţială a capitalului împrumutat.

Referitor la problematica impunerii de către creditorul profesionist a condiţiei achitării unui număr minim de rate; dreptul debitorului de rambursare anticipată persistă în toate cazurile; întrucât este vorba despre executarea obligaţiei principale a debitorului; însă având în vedere faptul că acesta contracarează efectele termenului contractual stipulat şi în interesul băncii; exerciţiul dreptului său va fi unul oneros; iar creditorul va fi îndreptăţit la o compensaţie obiectivă; după cum rezultă din textul art. 67 din O.U.G. nr. 50/2010 privind contractele de credit încheiate cu consumatorii; modificată prin O.U.G. nr. 52/2016 privind contractele de credit oferite consumatorilor pentru bunuri imobile. Una din ideile principale care se desprind din textul legal menţionat este aceea că creditorul profesionist are obligaţia de informa consumatorul încă din faza precontractuală asupra modalitătii de calcul al compensaţiei; modalitate care trebuie să fie clară; transparentă şi uşor verificabilă pe baza unor elemente obiective ${ }^{8}$.

În ceea ce priveşte cerinţa secundară; menţionată inclusiv în cuprinsul art. 16 din 2014/17/UE a Parlamentului European și a Consiliului privind contractele de credit oferite consumatorilor pentru bunuri imobile rezidențiale și de modificare a Directivelor 2008/48/CE și 2013/36/UE și a Regulamentului (UE) nr. 1093/2010; transpusă în dreptul intern prin O.U.G. nr. 52/2016 privind contractele de credit oferite consumatorilor pentru bunuri imobile; precum și pentru modificarea și completarea O.U.G. nr. 50/2010 privind contractele de credit pentru consumatori; aceasta se referă la interdicţia perceperii unei compensaţii de rambursare anticipată în cazurile în care restituirea anticipată a împrumutului intervine în perioade cu 
dobândă variabilă; când banca/creditorul a dispus de mecanisme obiective de ajustare a ratei dobânzii în funcţie de indicii de referinţă menţionaţi în mod clar în contract; fără a mai putea transfera ulterior pe umerii consumatorului pierderile financiare rezultate din recuperarea anticipată a capitalului. Ca argument pentru neincluderea acestor situaţii în sfera materială de incidenţă a dreptului creditorului la compensaţie echitabilă s-a adus observaţia ${ }^{9}$ că dobânda variabilă este în practică recalculată ori de câte ori indicii de referinţă menţionaţi în contract suferă modificări; ceea ce pune la adăpost creditorul cu privire la o serie de dezechilibre financiare decurgând din modificarea condițiilor de creditare; în vreme ce consumatorul nu beneficiază de o protecţie similară.

În fine; cea de a treia observaţie care poate fi enunţată pe marginea textului legal citat este aplicarea unui plafon legal uniformizat (la nivelul tuturor statelor-membre U.E.); pentru valoarea maximă a compensaţiei de rambursare anticipată. Această valoare a compensaţiei de rambursare anticipată nu poate depăşi: (a) $1 \%$ din valoarea creditului rambursată anticipat; dacă perioada de timp dintre rambursarea anticipată şi data convenită pentru încetarea contractului de credit este mai mare de un an; (b) 0;5\% din valoarea creditului rambursat anticipat; dacă perioada de timp dintre rambursarea anticipată şi data convenită pentru încetarea contractului de credit nu depăşeşte 12 luni.

\section{Interzicerea compensaţiei de rambursare anticipată în ipotezele enumerate în art. 68 din O.U.G. $\mathrm{nr}$ 50/2010 privind contractele de credit încheiate cu consumatorii. Ambiguitate legislativă sau asimetrie intenţionată?}

Ca urmare a exercitării dreptului de rambursare anticipată; consumatorul poate obţine o reducere a costului total al creditului; constând în dobânda şi costurile aferente perioadei dintre data rambursării anticipate şi data prevăzută pentru încetarea contractului de credit. Astfel cum a subliniat profesorul Jean Calais-Auloy ${ }^{10}$; profesioniştilor nu le este permis să condiţioneze rambursarea anticipată de plata unei anumite sume minime sau de un anumit număr de rate; punct de vedere care se regăseşte şi în redactarea textelor de lege aferente de către legiuitorul român (art. 66; alin. 1 şi 2 din O.U.G. privind contractele de credit încheiate cu consumatorii; cu completările şi modificările aduse prin O.U.G. nr. 52/2016 privind contractele de credite oferite consumatorilor pentru bunuri imobile; care prevede că debitorul consumator „are dreptul; în orice moment; să se libereze în tot sau în parte de obligațiile sale care decurg dintr-un contract de credit. În acest caz; consumatorul are dreptul la o reducere a costului total al creditului; această reducere constând în dobânda și costurile aferente perioadei dintre data rambursării anticipate și data prevăzută pentru încetarea contractului de credit. Dreptul consumatorului de a rambursa anticipat nu poate fi condiționat de plata unei anumite sume minime sau de un anumit număr de rate"). De asemenea; după cum rezultă din textul legal menţionat; creditorilor le este interzis să perceapă un comision de rambursare anticipată în următoarele trei cazuri; în care creditorul nu s-ar putea prevala de caracterul echitabil al compensaţiei de rambursare anticipată: 
(a) situaţiile în care rambursarea a fost realizată ca urmare a executării unui contract de asigurare având drept scop asigurarea riscului de neplată; după cum s-a arătat în literatura de specialitate ${ }^{11}$; în aceste ipoteze; rambursarea anticipată nu este voluntară şi nu are loc din iniţiativa debitorului; ci se produce ca urmare a survenirii riscului de neplată (insolvabilitatea debitorului) pe fondul existenţei între bancă şi o societate de asigurări; a unui contract de asigurare contra riscului de neplată. Alături de situaţiile în care rambursarea anticipată are loc în perioade de creditare în care rata dobânzii percepute nu este fixă; respectiv de situaţiile de contractare a unor servicii financiare sub forma descoperitului de cont; ipotezele în care rambursarea integrală creditului a fost realizată anticipat ca urmare a executării unui contract de asigurare reprezintă situaţii în care operează onterdicţia legală de percepere a unei compensaţii de rambursare anticipată de către creditorul profesionist; sumele percepute cu acest titku trebuind să fie restituite integral debitorului; inclusiv dobânda legală pentru intervalul dintre data plăţii acestor sume către dcreditor şi data restituirii efective a acestora către consumator;

(b) cazurile în care contractul de credit este acordat sub forma facilităţii de overdraft sau a „descoperitului de cont"; având în vedere că de esenţa descoperitului de cont ${ }^{12}$ este faptul că plăţile parţiale sau integrale făcute de consumator nu atrag stingerea creanţei; ci pot fi reutilizate imediat de către consumator ca sume disponibile în baza convenţiei de credit; mecanismul rambursării anticipate - care presupune stingerea totală sau parţială a creanţei prin plată - este incompatibil cu structura descoperitului de cont; care permite consumatorului să reutilizeze sumele rambursate pe durata menţionată. Creditul acordat sub forma descoperitului de cont presupune disponibilizarea capitalului împrumutat; în limita plafonului stabilit; cu fiecare plată făcută de consumator; funcţia plăţii nefiind în acest caz aceea de a stinge creanţa; ci de a plasa la dispoziţia debitorului pe durata contractului; fondurile plafonate contractual care depăşesc soldul creditor al contului curent al debitorului. Ca urmare; nu se poate vorbi despre o rambursare anticipată; întrucât creditorul s-a obligat să menţină respectivele sume la dispoziţia debitorului pe durata stabilită; astfel încât nu poate fi percepută o compensaţie de rambursare anticipată în cazul descoperitului de cont.

Se cuvine menţionat că; în ceea ce priveşte dreptul potestativ de denunţare unilaterală a contractului de descoperit de cont/facilitate de credit; acest drept nu poate fi exercitat de către creditor înainte de împlinirea termenului contractual decât pentru motive temeinice; „dacă acestea privesc beneficiarul facilităţii de credit”; după cum se exprimă legiuitorul în cuprinsul art. 2195 din Codul civil ${ }^{13}$. Din perspectiva efectelor ataşate exerciţiului dreptului potestativ de denunţare unilaterală a contractului de facilitate de credit; este necesar de remarcat faptul că denunţarea unilaterală a contractului de către creditor antrenează extincţia dreptului consumatorului de a utiliza sumele puse la dispoziţie în limita plafonului maxim; însă creditorul bancar are obligaţia să acorde debitorului/ consumatorului un termen de cel puţin 15 zile pentru restituirea sumelor utilizate şi a accesoriilor acestora; în acord cu dispoziţiile imperative ale art. 2195; alin. 2 din Codul civil. Dimpotrivă; în ipotezele în care contractul privind facilitatea de credit s-a încheiat pe durată nedeterminată; fiecare dintre părţi (atât creditorul bancar/societatea de servicii financiare; cât şi consumatorul debitor) poate să 
denunţe unilateral contractul; cu respectarea unui termen de preaviz de 15 zile; „dacă din contract sau din uzanţe nu rezultă astfel"; după cum se menţionează în cuprinsul art. 2195; alin. (3) Codul civil. Dreptul potestativ al consumatorului de denunţare unilaterală a contractului privind facilitatea de credit/ facilitatea de overdraft; în cazul convenţiilor de descoperit de cont; încheiate pe durată nedeterminată; nu trebuie confundat cu dreptul potestativ al consumatorului de rambursare anticipată a creditului; în pofida similitudinilor parţiale din materia efectelor juridice ale exerciţiului respectivului drept. Astfel; în timp ce opţiunea debitorului pentru denunţarea unilaterală a contractului de facilitate de credit încheiat pe durată nedeterminată îşi extrage fundamentele din principiul potrivit căruia părţile contractelor încheiate pe durată nedeterminată nu pot fi silite să rămână în respectiva relaţie contractuală în mod perpetuu (i); dreptul potestativ de rambursare anticipată a creditului este recunoscut debitorului pornind de la principiul potrivit căruia creditorul nu se poate opune executării voluntare de către debitor a obligaţiei principale de plată generate de convenţia de împrumut de bunuri consumptibile(ii);

(c) excluderea ipotezelor în care rambursarea anticipată intervine într-o perioadă în care rata dobânzii aferente creditului nu este fixă; în perioadele cu dobândă variabilă; creditorul a dispus de mecanisme obiective de ajustare a ratei dobânzii în funcţie de indicii de referinţă menţionaţi în contract. După cum a fost menţionat în literatura de specialitate care a tratat subiectul compensaţiei de rambursare anticipată ${ }^{14}$; dobânda variabilă este în practică recalculată ori de câte ori indicii de referinţă menţionaţi în contract suferă modificări; ceea ce plasează creditorul într-o zonă de siguranţă cu privire la o serie de dezechilibre decurgând financiar din modificarea condiţiilor de creditare; în vreme ce consumatorul nu beneficiază de o protecţie similară. De aceea; numai în cazul creditelor cu dobândă fixă; nu şi în cazul perioadelor de creditare cu dobândă variabilă; creditorul poate încasa o compensaţie echitabilă care să contracareze o parte din pierderile înregistrate la nivelul fructelor civile ale capitalului împrumutat. Însă rambursarea anticipată trebuie în toate cazurile să genereze o reducere a costului total al creditului pentru consumator; dispoziţiile legale citate limitând cuantumul compensaţiei care poate fi practicată la $1 \%$ din valoarea rambursată anticipat; pentru creditele cu durată mai mare de 1 an şi; respectiv la $0 ; 5 \%$ din valoarea rambursată anticipat; pentru creditele contractate pentru o durată sub un an. După cum am menţionat şi în cazul nerespectării de către creditorul profesionist a obligaţiei de transparenţă privind modul de calcul al compensaţiei; încălcarea acestor dispoziţii legale de către creditorul profesionist reprezintă contravenţie şi se sanç̧ionează cu amenda contravenţională; conform art. 86 din O.U.G. nr. 50/2010 privind contractele de credit încheiate cu consumatorii; cu modificările aduse prin O.U.G. nr. 52/2016 privind contractele de credite oferite consumatorilor pentru bunuri imobile.

Considerăm că; atât de lege lata; cât și de lege ferind; dispozițiile art. 68 din O.U.G. nr. 50/2010 privind contractele de credit încheiate cu consumatorii; cu modificările aduse prin O.U.G. nr. 52/2016 privind contractele de credite oferite consumatorilor pentru bunuri imobile trebuie interpretate în sensul în care creditorul bancar; în materia produselor de creditare privind finanțarea achiziției; consolidării; extinderii bunurilor imobile; are dreptul să perceapă o compensație pentru rambursare anticipată; în limitele plafonului legal; chiar și 
în situațiile în care rata dobânzii percepute este variabilă. În opinia noastră; este o scăpare a legiuitorului român faptul de a nu menționa în cuprinsul art. 68 din ordonanța de guvern citată faptul că sunt exceptate creditele de investiții imobiliare acordate consumatorului; în materia cărora să opereze dreptul creditorului de a percepe o compensație de rambursare anticipată în toate situațiile; indiferent de modalitatea de stabilire a ratei dobânzii (fixă sau variabilă). De exemplu; legiuitorul din Serbia a menționat în cuprinsul art. 36 din Legea nr. 73/2012 pentru protecția consumatorilor de servicii financiare ${ }^{15}$; faptul că nu poate fi percepută o compensație pentru rambursare anticipată în situațiile în care în care rambursarea anticipată intervine într-o perioadă în care rata dobânzii aferente creditului nu este fixă; cu excepția creditelor pentru investiții imobiliare; în cazul cărora perceperea unei compensații este permisă indiferent de tipul dobânzii; în limitele plafonului legal. Considerăm că o asemenea mențiune expresă ar fi fost utilă și în legislația română privitoare la creditele de investiții imobiliare contractate de consumatori; astfel încât prevederile art. 68 din O.U.G. nr. 50/2010 privind contractele de credit încheiate cu consumatorii; cu modificările aduse prin O.U.G. nr. 52/2016 privind contractele de credite oferite consumatorilor; care interzic creditorilor profesioniști perceperea unei compensații de rambursare anticipată a creditului în situația existenței unei rate variabile a dobânzii; să fie circumscrise la cazurile creditelor pentru consum; respectiv de nevoi personale nenominalizate fără garanții reale imobiliare.

\section{Plafonarea prin dispoziţii imperative a compensaţiei de rambursare anticipată}

După cum sublinia profesorul Guy Raymond ${ }^{16}$; normele privitoare la plafonarea valorii compensaţiei la care este îndreptăţit creditorul în ipoteza rambursării anticipate prezintă un caracter imperativ; nefiind permisă derogarea prin clauze contractuale care ar tinde să depăşească plafonul maxim legal. Textul art. 69 din O.U.G. nr. 50/2010 privind contractele de credit încheiate cu consumatorii; cu modificările ulterioare; stabileşte un plafon maxim global pentru valoarea compensaţiei de rambursare anticipată; corespunzător dispoziţiilor art. 16 din Directiva 2008/48/CE a Parlamentului European şi a Consiliului din 23 aprilie 2008 privind contractele de credit pentru consumatori; statuând că valoarea compensaţiei cuvenite creditorului nu poate depăşi cuantumul dobânzii pe care consumatorul ar fi plătit-o în perioada dintre rambursarea anticipată şi data convenită pentru încetarea contractului de credit. Prin urmare; limita maximă aplicabilă valorii compensaţiei de rambursare anticipată este cea rezultând din valoarea dobânzii pe care ar fi perceput-o creditorul în intervalul de timp pentru care are loc plata anticipată.

Pentru creditele cu dobândă fixă; creditorul bancar poate încasa o compensaţie echitabilă care să contracareze o parte din pierderile înregistrate la nivelul dobânzii; însă rambursarea anticipată trebuie în toate cazurile să conducă în mod logic la o reducere a costului total al creditului pentru consumator; astfel încât compensaţia stabilită de bancă nu va putea depăşi; ci eventual egala valoarea dobânzii pe care ar fi plătit-o in respectivul interval consumatorul. 
Considerăm că; deşi textul legal naţional; ca şi cel al art. 16 din directiva europeană menţionează expres cuantumul cărei dobânzi va fi luat în calcul ca plafon maxim; este vorba despre dobânda fixă stipulată în contract cu titlu de fructe civile generate de capitalul împrumutat; iar nu despre DAE - dobânda anuală efectivă. În opinia noastră; valoarea dobânzii fixe va fi luată ca reper (plafon legal pentru valoarea maximă a compensaţiei de rambursare anticipată); iar nu valoarea DAE (costul total al creditului); având în vedere că respectivul cost total poate include şi comisioane bancare percepute pentru prestarea de către creditorul bancar a unor servicii suplimentare sau conexe în respectivul interval. Or; ca urmare a rambursării anticipate; respectivele servicii conexe/suplimentare nu vor mai fi prestate către consumator pentru numărul de luni pentru care are loc rambursarea anticipată a creditului; ceea ce înseamnă că aceste comisioane (în accepţiunea de plată a unor servicii prestate cu caracter autonom) nu vor fi datorate de către consumator. Considerăm că raţiunea compensaţiei de rambursare anticipată este aceea de a acoperi o parte din pierderea financiară rezultată din neîncasarea fructelor civile (a dobânzii propriuzise) pe care capitalul împrumutat le-ar fi generat conform contractului în intervalul stabilit; iar DAE include şi costuri pentru servicii practicate de bancă; precum serviciul de administrare a contului bancar; or prin rambursarea anticipată acest serviciu nu mai este necesar/nu va mai fi prestat; ceea ce exclude raţiunea unei compensaţii suplimentare.

După cum am menţionat în paragrafele precedente; legiuitorul european şi cel naţional au făcut uz de două plafoane legale incidente în materia comisioanelor de rambursare anticipată. Mai întâi; se va aplica plafonul legal relativ la cuantumul maxim al compensaţiei; de $1 \%$ din valoarea rambursată anticipat; pentru creditele cu durată mai mare de 1 an şi; respectiv la 0;5\% din valoarea rambursată anticipat; pentru creditele cu durata sub un an. Subsecvent; se va verifica încadrarea în cel de-al doilea plafon legal; privitor la valoarea dobânzii în intervalul stipulat în contract; astfel încât; de exemplu; suma rezultată din aplicarea calculului de $1 \%$; respectiv de $0 ; 5 \%$ din valoarea rambursată anticipat să nu depăşească suma pe care banca ar fi perceput-o cu titlu de dobândă în intervalul contractual stabilit iniţial. Încălcarea acestor dispoziţii legale de către creditorul profesionist reprezintă contravenţie şi se sanç̧ionează cu amenda contravenţională; conform art. 86 din O.U.G. nr. 50/2010 privind contractele de credit încheiate cu consumatorii; cu modificările şi completările ulterioare.

\section{Nulitatea clauzelor privind renunţarea consumatorilor la dreptul de rambursare anticipată}

Din dispoziţiile art. 80; alin. (1) din O.U.G. nr. 50/2010 privind contractele de credit încheiate cu consumatorii; cu modificările şi completările aduse prin O.U.G. nr. 52/2016 privind contractele de credite oferite consumatorilor pentru bunuri imobile rezultă că clauzele de renunţare a consumatorului la drepturile conferite prin OUG nr. 50/2010 sunt lovite de nulitate. Astfel; se poate reţine că sunt lovite de nulitate stipulaţiile contractuale prin care creditorul profesionist propune consumatorului să renunţe la unul sau mai multe 
din drepturile sale legale; inclusiv la dreptul de rambursare anticipată a creditului şi la aplicarea normelor legale imperative privind plafonarea compensaţiei creditorului pentru rambursarea anticipată. În ceea ce priveşte tipul de nulitate (absolută; imprescriptibilă şi imposibil de confirmat sau; dimpotrivă; o nulitate relativă; prescriptibilă; care ar putea fi invocată doar de persoana ocrotită şi de succesorii săi în drepturi cu titlu universal/universali; actul putând fi confirmat); legiuitorul a evitat să califice această specie de nulitate; ceea ce lasă loc de echivoc; permiţând aducerea de argumente în sprijinul ambelor variante. Astfel; s-ar putea susţine că; atunci când a dorit să instituie un caz de nulitate absolută; legiuitorul a menţionat această calificare în mod expres (i); respectiv că nulutatea absolută reprezintă o situaţie de excepţie; iar nu regula (ii); ca argumente pentru a reţine caracterul de nulitate relativă a sanç̧iunii aplicabile clauzelor care aduc atingere dreptului consumatorului de rambursare anticipată.

Pornind de la exprimarea eliptică a legiuitorului (,,sunt lovite de nulitate”); cumulat cu argumentul extras din natura interesului privat ocrotit/interesele legitime; economice ale consumatorului debitor; s-ar putea extrage concluzia consacării prin dispoziţiile art. 80; alin. (1) din O.U.G. nr. 50/2010 cu modificările aduse prin O.U.G. nr. 52/2016 privind contractele de credite oferite consumatorilor pentru bunuri imobile; a unui caz de nulitate relativă. Principala obiecţie care s-ar putea ridica ar fi cea legată de caracterul prescriptibil în termenul general de 3 ani al dreptului la acţiunea în anulare; care s-ar calcula de la data semnării contractului cuprinzând clauza anulabilă; ceea ce ar atrage soluţii ilogice în cazul consumatorilor care decid să-şi exercite dreptul de rambursare anticipată (care nu se stinge prin semnarea clauzei abuzive de renunţare anticipată) şi care îşi exercită respectivul drept după un interval mai mare de 3 ani de derulare a raporturilor contractuale de credit. Considerăm că; deşi interesul ocrotit este unul privat; iar nu unul de ordine publică; acţiunea consumatorului în reprimarea clauzei abuzive de renunţare anticipată la drepturile consumatorului recunoscute prin dispoziţiile imperative ale legii este imprescriptibilă; iar sancţiunea adecvată ar fi reputarea/considerarea clauzei ca nescrisă ${ }^{17}$.

Considerăm că; în cazul obligaţiei de transparenţă şi al obligaţiei de informare incumbând profesioniştilor; pot fi remarcate două particularităţi:

(a) prezumţia absolută; irefragabilă de bună cunoaştere a domeniului; în sensul în care profesionistului creditor nu i se acceptă proba contrară; a insuficientei cunoaşteri a normelor domeniului în care activează; în încercarea de a se exonera de răspundere pentru neexecutarea obligaţiei precontractuale de informare/ obligaţiei bancare de transparenţă;

(b) inversarea sarcinii probei privind executarea obligaţiei de informare/transparenţă; în sensul în care consumatorului nu i se solicită să facă dovada; imposibilă; a unui fapt negativ (faptul că executarea obligaţiei de informare nu a avut loc); sarcina probei executării incumbând profesionistului; acesta trebuind să furnizeze dovada executării corespunzătoare a obligaţiei precontractuale de informare/de transparenţă bancară. De aceea; revine profesionistului bancar sarcina de a-şi preconstitui mijloace suficiente de dovadă (pe hârtie sau alt suport durabil) în legătură cu executarea faţă de consumator a obligaţiei legale de informare. 


\section{Domeniul de aplicare rationae personae şi rationae materiae al dispoziţiilor legale privind dreptul potestativ de rambursare anticipată}

Interogaţiile privind sfera personală de aplicare a dispoziţiilor legale referitoare la dreptul de rambursare anticipată şi la plafonarea compensaţiei percepute de creditor în cazul rambursării integrale sau parţiale; anticipate a creditului pornesc de la ideea de a şti în ce măsură persoanele fizice care contractează în scop profesional ar putea beneficia de protecţia legală privitoare la plafonarea sumelor compensatorii acordate creditorului. Răspunsul nu poate fi decât negativ; având în vedere că atât dispoziţiile directivei europene în materia creditelor pentru consum; cât şi dispoziţiile O.U.G. nr. 50/2010 privind contractele de credit; cu modificările ulterioare aduse prin O.U.G. nr. 52/2016 privind contractele de credite oferite consumatorilor pentru bunuri imobile se referă la consumatori; în accepţiunea de persoane fizice care contractează creditul în scopuri situate în afara unei activităţi profesionale; comerciale; artizanale sau industriale.

Din perspectiva domeniului de aplicare rationae materiae al dispoziţiilor privind obligaţia creditorilor profesionişti de transparenţă în ceea ce priveşte maniera de stabilire a cuantumului compensaţiei de rambursare anticipată; noţiunea de acţiune înşelătoare sau de omisiune înşelătoare - ca forme de practici comerciale neloiale - se pot materializa atât în omiterea de către creditorul profesionist a menţionării informaţiilor; în faza precontractuală şi în momentul semnării contractului de credit; privitoare la modalitatea obiectivă de calcul a valorii compensaţiei de rambursare anticipată (a); cât şi la acţiuni înşelătoare; cum ar fi utilizarea de formule de calcul netransparente; fondate pe elemente echivoce (cum ar fi clauzele privind „politica monetară a creditorului bancar"). După cum a fost menţionat în decizia CJUE; în cazul Trento Sviluppo şi Centrale Adriatica Soc. coop. v. Autorità Garante della Concorrenza e del Mercato ${ }^{18}$; o practică comercială poate fi calificată drept înşelătoare în sensul art. 6; alin. (1) din Directiva 2005/29/CE a Parlamentului European şi a Consiliului din 11 mai 2005 privind practicile comerciale neloiale faţă de consumatori şi de modificare a Directivei 84/450/CEE; a Durectiuvei 97/7/CE şi 2002/65/CE şi a Regulamentului (CE) nr. 2006/2004; privind practicile comerciale neloiale ${ }^{19}$; în cazul în care respectiva practică ar conţine informaţii false sau susceptibile de a indice în eroare consumatorul mediu ${ }^{20}$; fiind totodată de natură să determine luarea de către consumatorul mediu a unei decizii de contractare pe care nu ar fi luat-o dacă ar fi fost în posesia unor informaţii detaliate. Considerăm că întrunesc elementele acestei definiţii a practicilor neloiale în relaţiile cu consumatorii; practicile creditorilor profesionişti de a omite în etapa formării contractului de credit; a informaţiilor esenţiale privitoare la dreptul consumatorului de rambursare anticipată şi la modalitatea de calcul a compensaţiei achitate creditorului; respectiv furnizarea de informaţii false; eronate; incomplete sau echivoce privind modalitatea de calcul a valorii compensaţiei de rambursare anticipată. 


\section{Calificarea încălcării de către creditorul profesionist a unor obligaţii specifice în raporturile cu debitorul consumator}

În ceea ce priveşte calificarea încălcării de către creditorul profesionist a unor obligaţii specifice în raporturile cu debitorii consumatori; în accepţiunea de persoane fizice care contractează creditul în scopuri extraprofesionale; textul art. 86 din O.U.G. nr. 50/2010 privind contractele de credit; cu modificările ulterioare; se referă la calificarea drept contravenţii a faptelor de încălcare de către creditorii profesionişti a anumitor dispoziţii legale imperative; incidente în materia raporturilor contractuale de credit între profesionişti şi consumatori:

(a) mai întâi; sunt vizate dispoziţiile legale referitoare la obligaţia de informare a consumatorilor prin documentele publicitare (conform dispoziţiilor art. 8 din O.U.G. nr. 50/2010 privind contractele de credit pentru consumatori; cu modificările aduse prin O.U.G. nr. 52/2016 privind contractele de credite oferite consumatorilor pentru bunuri imobile);

(b) în al doilea rând; sunt incidente dispoziţiile legale privitoare la menţiunile obligatorii şi la exemplul de calcul reprezentativ în mesajele publicitare de promovare a ofertelor de credit (art. 9 din OUG nr. 50/2010; privind contractele de credit pentru consumatori; cu modificările aduse prin O.U.G. nr. 52/2016 privind contractele de credite oferite consumatorilor pentru bunuri imobile);

(c) în cel de-al treilea rând; este vizată încălcarea prevederilor legale imperative în materia informaţiilor precontractuale care trebuie furnizate în mod obligatoriu consumatorilor în faza precontractuală; uzul Formularului informativ european standardizat; obligaţia de informare incumbând intermediarilor de credite ş.a.; conform dispoziţiilor art. 11-20 din OUG nr. 50/2010; privind contractele de credit pentru consumatori; cu modificările aduse prin O.U.G. nr. 52/2016 privind contractele de credite oferite consumatorilor pentru bunuri imobile ;

(d) pe de altă parte; reprezintă contravenţie nerespectarea dispoziţiilor legale referitoare la furnizarea informaţiilor standard către consumator în faza precontractuală; pe hârtie sau pe alt suport durabil şi redactate în scris; vizibil şi uşor de citit; cu cel puţin 15 zile înainte ca acesta să încheie un contract de credit; conform art. 22-28 din OUG nr. 50/2010; modificată prin O.U.G. nr. 52/2016 privind contractele de credite oferite consumatorilor pentru bunuri imobile;

(e) prevederile art. 29; alin. (2) privitoare la obligaţia creditorului profesionist de a se asigura că informaţiile precontractuale prevăzute în articolele respective au fost primite de consumator; precum şi dispoziţiile art. 31-32 privitoare la obligaţia creditorului de a evalua bonitatea consumatorului şi accesul la bazele de date;

(f) totodată; săvârşeşte contravenţie creditorul profesionist care încalcă dispoziţiile legale relative la formalismul informativ aplicabil contractului de credit - art. 33 din OUG nr. 50/2010 privind contractele de credit pentru consumatori; cu modificările aduse prin O.U.G. nr. 52/2016 privind contractele de credite oferite consumatorilor pentru bunuri imobile; 
conform căruia contractele de credit trebuie redactate în scris; vizibil şi uşor de citit; pe hârtie sau pe un alt suport durabil; dispoziţiile legale conform cărora contractele de credit trebuie să conţină informaţii complete; clare şi uşor de înţeles; respectiv cerinţele legale relative la obligaţia creditorilor de a da explicaţii suplimentare; la cererea expresă a consumatorului; înainte de semnarea contractului; sub forma unei note; anexată la contract;

(g) dispoziţiile legale imperative privitoare la dreptul consumatorului de a primi un exemplar original al contractului de credit; în momentul semnării acestuia; conform art. 34;

(h) exigenţele legale referitoare la formalismul informativ aplicabil contractului de credit; care presupune anumite cerinţe privind conţinutul obligatoriu al contractului; respectiv inserarea în cuprinsul contractului de credit; în scris; a menţiunilor obligatorii specificate de către legiuitor; în mod expres şi fără a face trimitere la condiţiile generale de afaceri ale creditorului; la lista de tarife şi comisioane sau la orice alt înscris; conform art. 46-58 din O.U.G. nr. 50/2010 privind contractele de credit pentru consumatori; cu modificările aduse prin O.U.G. nr. 52/2016 privind contractele de credite oferite consumatorilor pentru bunuri imobile; dispoziţiile legale referitoare la informarea consumatorului asupra ratei dobânzii; conform cărora consumatorul este informat; pe hârtie sau pe alt suport durabil; în legătură cu orice modificare a ratei dobânzii aferente creditului îndeosebi cu privire la valoarea plăţilor de efectuat după intrarea în vigoare a noii rate a dobânzii aferente creditului ${ }^{21}$;

(i) dispoziţiile art. 35; prin care sunt interzise anumite practici bancare; este vorba despre: interzicerea majorării pe parcursul derulării contractului a comisioanelor; tarifelor şi spezelor bancare; cu excepţia costurilor impuse prin legislaţie; de asemenea; este interzisă introducerea şi perceperea de noi comisioane; tarife sau a oricăror alte speze bancare; $c u$ excepţia costurilor specifice unor produse şi servicii suplimentare solicitate în mod expres de consumator; neprevăzute în contract ori care nu erau oferite consumatorilor la data încheierii acestuia ${ }^{22}$;

(j) modalitatea de calcul al dobânzii variabile; dispoziţiile legale imperative referitoare la cuantumul dobânzii penalizatoare; încheierea actelor adiţionale; predarea către consumator a documentelor care atestă executarea contractului; conform dispoziţiilor art. 38-44 din O.U.G. nr. 50/2010 privind contractele de credit încheiate cu consumatorii; cu modificările şi completările ulterioare aduse prin O.U.G. nr. 52/2016 privind contractele de credite oferite consumatorilor pentru bunuri imobile ${ }^{23}$.

După cum am menţionat; textul art. 88 aduce precizări; pe de o parte cu privire la sanç̧iunile complementare pe care le poate aplica agentul constatator al contravenţiei contra creditorului care a încălcat dispoziţiile imperative ale O.U.G. nr. 50/2010 privind contractele de credit încheiate între profesionişti şi consumatori cu modificările aduse prin O.U.G. nr. 52/2016 privind contractele de credite oferite consumatorilor pentru bunuri imobile şi; pe de altă parte; cu privire la efectele contestaţiei în instanţă de către creditorii profesionişti a sanç̧iunilor contravenţionale; precizându-se că aceste contestaţii nu sunt suspensive de executare a sanç̧iunilor contravenţionale. Tipologia măsurilor sancţionatării care pot fi dispuse contra creditorilor contravenienţi este mai vastă; aceasta incluzînd nu numai aplicarea 
amenzii contravenţionale; ci şi o serie de măsuri complementare. Sanç̧iunile contravenţionale complementare care pot fi dispuse de către agentul constatator; ca urmare a constatării contravenţiei; sunt; după cum rezultă din textul art. 88 din O.U.G. nr. 50/2010 privind contractele de credit încheiate între profesionişti şi consumatori; cu modificările aduse prin O.U.G. nr. 52/2016 privind contractele de credite oferite consumatorilor pentru bunuri imobile:

(i) cea dintâi măsură complementară constă în obligarea creditorului profesionist la respectarea imediată a clauzelor contractuale care au fost încălcate;

(ii) în al doilea rând; se poate dispune restituirea de către creditor a sumelor încasate fără temei legal de la consumator; într-un termen de maximum 15 zile; de exemplu; dacă agentul constatator a înregistrat săvârşirea unei contravenţii sub forma perceperii de către creditorul profesionist a unui comision interzis (cum ar fi nerespectarea plafonului legal maxim pentru valoarea compensaţiei de rambursare anticipată a creditului; perceperea unui comision de analiză dosar fără acordarea creditului; comision de depunere numerar pentru plata ratelor; comision de retragere din cont a sumelor puse la dispoziţie cu titlu de credit; comision pentru schimbarea scadenţei ratelor; comision pentru schimbarea garanţiilor); sumele percepute ilegal trebuie restituite consumatorilor în decurs de 15 zile de la constatarea contravenţiei;

(iii) cea de a treia sancţiune complementară se referă la aducerea contractului în conformitate cu prevederile legale; de către creditorul profesionist; în termen de maximum 15 zile; de exemplu; în cazul constatării unei contravenţii în forma introducerii în contractele de credit a unor clauze abuzive (cum ar fi clauza de renunţare a consumatorului la dreptul de rambursare anticipată; clauza de modificare unilaterală a contractului de către creditor fără încheierea unui act adiţional; clauza de confidenţialitate care obligă clientul să nu desconspire conţinutul contractului de credit; clauza relativă la penalizarea consumatorului de către creditor pentru afectarea reputaţiei băncii; clauza de scadenţă anticipată a obligaţiei de rambursare a creditului pentru neexecutarea contractelor încheiate de consumator cu alţi creditori; clauza de impunere a identităţii societăţii de asigurări); agentul constatator va dispune readucerea contractelor la o formă acceptată de lege; prin eliminarea din contracte a clauzelor abuzive; având la dispoziţie un interval de 15 zile în acest scop;

(iv) în fine; cea de a patra sancţiune complementară implică repararea deficienţelor constatate prin procesul-verbal; în termen de maximum 15 zile de la dispunerea măsurilor sancţionatorii de către agentul constatator.

De remarcat că neaducerea la îndeplinire a sancţiunilor contravenţionale complementare dispuse în termenele şi condiţiile prevăzute în procesele-verbale de constatare a contravenţiei; respectiv săvârşirea repetată; în decurs de 6 luni de la prima constatare a uneia dintre contravenţiile prevăzute la art. 86 alin. (1) din O.U.G. nr. 50/2010 privind contractele de credit încheiate între profesionişti şi consumatori; cu modificările aduse prin O.U.G. nr. 52/2016 privind contractele de credite oferite consumatorilor pentru bunuri imobile constituie la rândul său contravenţie şi se sanç̧ionează cu amendă contravenţională. 
Plafoanele legale menţionate în cuprinsul art. 86 pot fi depăşite în cazul unor amenzi cumulative; aplicate pentru reclamaţii diferite; până la dublul valorii amenzilor contravenţionale dispuse iniţial.

\section{Sancţiunile complementare aplicabile profesioniştilor pentru încălcarea unor obligaţii specifice în contractele de credit}

Textul art. 89 din O.U.G. nr. 50/2010 privind contractele de credit încheiate cu consumatorii; cu modificările ulterioare aduse prin O.U.G. nr. 52/2016 privind contractele de credite oferite consumatorilor pentru bunuri imobile prevede două sanç̧iuni complementare care pot fi aplicate profesioniştilor bancari; ca accesoriu al sancţiunii principale (amenda contravenţională) pentru încălcarea exigenţelor legale aplicabile ofertelor de credit; respectiv pentru încălcarea obligaţiei de transparenţă în faza precontractuală (privind informarea consumatorului asupra modalităţii de calcul al compensaţiei de rambursare anticipată; modalitate care trebuie să fie clară; transparentă şi verificabilă pe baza unor elemente obiective).

În cuprinsul art. 9 din O.U.G. nr. 50/2010 privind contractele de credit pentru consumatori; cu modificările aduse prin O.U.G. nr. 52/2016 privind contractele de credite oferite consumatorilor pentru bunuri imobile; autorilor şi beneficiarilor publicităţii făcute ofertelor de credit li se solicită să se supună unor reguli clare relative la formă (scrierea cu caractere vizibile şi uşor de citit; în acelaşi câmp vizual şi cu caractere lizibile) şi la conţinut (cum ar fi exigenţele privitoare la includerea obligatorie a unui exemplu de calcul reprezentativ). Textul legal citat impune setul de reguli menţionat pentru orice formă de publicitate făcută ofertelor de credit; independent de tipul dobânzii percepute; fixă sau variabilă. Considerăm că; în situaţiile în care; în practică; pliantele publicitare utilizate de societăţile bancare/de servicii financiare exclud detaliile referitoare la dobânda practicată; DAE şi exemplul de calcul reprezentativ (sub pretextul caracterului informativ al mesajului sumar); A.N.P.C. poate dispune suspendarea derulării campaniei publicitare care încalcă prevederile art. 8 şi 9; până la intrarea în legalitate.

După cum am menţionat în paragrafele anterioare; reprezintă practici înşelătoare susceptibile de sancţionare şi situaţiile în care un produs de creditare este prezentat consumatorului în materiale publicitate incomplete (care nu conţin informaţiile standard minimale; în baza unui exemplu de calcul reprezentativ; privitoare la dobânda şi comisioanele ataşate produsului de creditare); fără a se explica/identifica contrapartida financiară aplicabilă (dobândă fixă/variabilă sau mixtă; comisioane pentru servicii acordare la solicitarea consumatorului; compensaţii datorate creditorului pentru rambursarea anticipată s.a.).

De asemenea; se poate sublinia că; în actuala reglementare; publicitatea ofertelor de credit rămâne principala zonă insuficient detaliată în cuprinsul textelor legale; de pildă; nu se interzice utilizarea de materiale publicitare sumare; aparent „informative”; din care lipseşte 
exemplul de calcul reprezentativ sau sunt absente menţiunile referitoare la dobânda şi comisioanele practicate pentru servicii suplimentare sau conexe de către creditorul bancar/ societatea de servicii financiare. Considerăm că o asemenea interdicţie legală explicită ar fi utilă de lege ferenda; ţinând seama că textul Directivei 2014/17/UE a Parlamentului European și a Consiliului privind contractele de credit oferite consumatorilor pentru bunuri imobile rezidențiale și de modificare a Directivelor 2008/48/CE și 2013/36/UE și a Regulamentului (UE) nr. 1093/2010; transpusă în dreptul intern prin O.U.G. nr. 52/2016 privind contractele de credit oferite consumatorilor pentru bunuri imobile; precum și pentru modificarea și completarea O.U.G. nr. 50/2010 privind contractele de credit pentru consumatori. este unul de protecţie minimală; statelor-membre fiindu-le permis să accentueze protecţia legală acordată consumatorilor în raport cu tendinţele naţionale manifestate în practica judiciară.

Se cuvine reamintit faptul că cerinţele imperative şi exigenţele cuprinse în art. 9 din O.U.G. nr. 50/2010 privind contractele de credit pentru consumatori; cu modificările aduse prin O.U.G. nr. 52/2016 privind contractele de credite oferite consumatorilor pentru bunuri imobile se referă la includerea în mesajul publicitar; a unor informaţii-standard care specifică; prin intermediul unui exemplu de calcul reprezentativ; următoarele: (a) rata dobânzii aferente creditului; fixă şi/sau variabilă; împreună cu informaţii privind orice costuri incluse în costul total al creditului pentru consumator; (b) valoarea totală a creditului; (c) dobânda anuală efectivă; (d) durata contractului de credit; (e) în cazul unui credit sub formă de amânare la plată pentru un anumit bun sau serviciu; preţul de achiziţie şi valoarea oricărei plăţi în avans; (f) după caz; valoarea totală plătibilă de către consumator şi valoarea ratelor.

Măsura complementară a suspendării campaniei publicitare iniţiate de creditor poate fi dispusă de A.N.P.C. (ori de către instanţa de judecată; în cazul unui litigiu) nu numai pentru omisiunea uneia din informaţiile-standard amintite; ci şi strict pentru forma în care este livrată această informaţie (mesaj neclar; exces de informaţie; text ilizibil; informaţii scrise cu caractere mici în raport cu mesajul publicitar incitativ ${ }^{24}$ ş.a.). După cum se menţionează expres în textul art. 9; alin. (2) din O.U.G. nr. 50/2010 privind contractele de credit încheiate cu consumatorii; cu modificările şi completările aduse prin O.U.G. nr. 52/2016 privind contractele de credite oferite consumatorilor pentru bunuri imobile;; "În orice formă de publicitate; informaţiile prevăzute la alin. (1) sunt scrise în mod clar; concis; vizibil şi uşor de citit; în acelaşi câmp vizual şi cu caractere de aceeaşi mărime."

După cum a subliniat profesorul Bonneau ${ }^{25}$; o altă informaţie esenţială care trebuie inclusă în mod obligatoriu în publicitatea ofertelor de credit este cea referitoare la asigurările obligatorii ataşate contractului principal. în ipotezele în care încheierea unui contract referitor la un serviciu accesoriu aferent contractului de credit; îndeosebi un anumit tip de asigurare; este obligatorie pentru aprobarea creditului; iar costurile respectivului serviciu nu pot fi determinate anticipat; obligativitatea încheierii unui asemenea contract este; la rândul său; menţionată în mod explicit; concis şi vizibil; la fel ca valoarea dobânzii anuale efective; conform dispoziţiilor art. 9; alin. (3) din O.U.G. nr. 50/2010 privind contractele de credit încheiate între profesionişti şi consumatori privind contractele de credit pentru consumatori; cu modificările aduse prin O.U.G. nr. 52/2016 privind contractele de 
credite oferite consumatorilor pentru bunuri imobile. Considerăm că; dacă această informaţie lipseşte; pe lângă amenda contravenţională; se poate aplica şi sancţiunea complementară a suspendării campaniei publicitare până la aducerea materialelor publicitare la conformitate.

Menţionăm că; suplimentar faţă de sanç̧iunile prevăzute de art. 89 din O.U.G. nr. 50/2010 privind contractele de credit încheiate între profesionişti şi consumatori; cu modificările aduse prin O.U.G. nr. 52/2016 privind contractele de credite oferite consumatorilor pentru bunuri imobile; afișajul hotărârii judecătoreşti (de condamnare) poate reprezenta o sanç̧iune accesorie dispusă de către instanţa de judecată; complementar sanç̧iunii principale ${ }^{26}$ (cum ar fi plata de daune-interese) în urma admiterii acţiunii introduse de către un consumator sau de către o asociaţie de consumatori; constând în condamnarea profesionistului pârât la difuzarea publică a hotărârii judecătoreşti de condamnare; pe cheltuiala sa; calea de difuzare fiind aleasă în funcţie de pertinenţa acesteia (publicarea unui comunicat în presa scrisă; difuzarea unui comunicat televizat ori a unuia radiofonic; reproducerea în presă a deciziei instanţei; afişaj s..a.); în mod evident; metoda comunicatului rectificativ poate avea efecte disuasive importante; dat fiind impactul său asupra reputaţiei comerciale a pârâtului. Ca ipoteză de exemplificare; putem dicuta cazul în care; după rămânerea definitivă şi irevocabilă a hotărârii judecătoreşti; în vederea eliminării efectelor unei practici comerciale incorecte; s-a dispus încetarea; respectiv interzicerea acesteia; instanţa de judecată putând solicita publicarea deciziei; integral sau parţial; în forma pe care o consideră adecvată; într-un ziar de largă circulaţie; pe cheltuiala comerciantului; conform dispoziţiilor art. 13 alin. (3) din Legea nr. 363/2007 privind combaterea practicilor incorecte ale comercianţilor în relaţia cu consumatorii şi armonizarea reglementărilor cu legislaţia europeană privind proteç̧ia consumatorilor; cu modificările şi completările aduse prin O.G. nr. 37/2015 pentru modificarea unor acte normative din domeniul protecției consumatorilor; aprobată cu modificări prin Legea nr. 51/2016 pentru aprobarea O.G. nr. 37/2015 pentru modificarea unor acte normative din domeniul protecției consumatorilor ${ }^{27}$

Într-o altă ordine de idei; cea de-a doua măsură complementară; adiacentă celor prevăzute de art. 89 din O.U.G. nr. 50/2010 cu modificările aduse prin O.U.G. nr. 52/2016 privind contractele de credite oferite consumatorilor pentru bunuri imobile; este cea a comunicatului rectificator prevăzut de art. 13; alin. (2); lit. b) din Legea nr. 363/2007 privind combaterea practicilor incorecte ale comercianţilor în relaţia cu consumatorii şi armonizarea reglementărilor cu legislaţia europeană privind protecţia consumatorilor; cu modificările şi completările aduse prin O.G. nr. 37/2015 pentru modificarea unor acte normative din domeniul protecției consumatorilor; aprobată cu modificări prin Legea nr. 51/2016. Se cuvine reamintit faptul că; din perspectiva efectelor sale; comunicatul rectificator reprezintă o sancțiune accesorie ${ }^{28}$ dispusă de către A.N.P.C.; respectiv instanţa de judecată; complementară sanç̧iunii principale (cum ar fi plata de daune-interese) în urma admiterii acţiunii introduse de către un consumator/o asociaţie de consumatori în reprimarea publicităţii înşelătoare/ comparative ilicite; constând în condamnarea profesionistului pârât la difuzarea publică a unui anunţ de rectificare a mesajului publicitar anterior şi care a conţinut alegaţii false (de natură a induce în eroare consumatorul mediu şi de a influenţa în mod decisiv comportamentul economic al acestuia). Menţionăm că publicarea anunţului rectificator are loc pe cheltuiala profesionistului bancar; calea de difuzare 
fiind aleasă în funcţie de pertinenţa acesteia (publicarea unui comunicat în presa scrisă; difuzarea unui comunicat televizat ori a unuia radiofonic; reproducerea literală în presă; afişaj ş.a.); alături sau independent de afişajul hotărârii judecătoreşti de condamnare; anunţul rectificator poate avea efecte disuasive importante; dat fiind impactul său asupra reputaţiei comerciale a creditorului profesionist.

De remarcat că sanç̧iunea complementară; a aducerii integrale a contractelor similare în conformitate cu prevederile legale; în termen de 30 de zile; poate însoţi amenda contravenţională aplicată pentru încălcarea prevederilor legale privitoare la: (a) inserarea de clauze contractuale privind perceperea unor comisioane bancare interzise de dispoziţiile legale imperative; (b) nerespectarea cerinţelor formalismului informativ (omiterea informaţiilor obligatorii din textul contractual); (c) exigenţele formale aplicabile conform art. 33 din O.U.G. nr. 50/2010 privind convenţiile de credit încheiate cu consumatorii; cu modificările aduse prin O.U.G. nr. 52/2016 privind contractele de credite oferite consumatorilor pentru bunuri imobile; contractele de credit trebuind să fie redactate în scris; în mod vizibil; pe hârtie sau pe un alt suport durabil; sub sancţiunea amenzii contravenţionale şi/sau a obligării creditorului la refacerea formularelor contractuale standard (contracte de adeziune). Considerăm că; din perspectiva criteriilor de apreciere a existenţei unei practici neloiale în materia serviciilor financiare contractate între profesionişti şi consumatori; criteriul obiectiv al prezenţei unor informaţii false prevalează asupra criteriului subiectiv; al existenţei sau inexistenţei intenţiei de a induce în eroare consumatorii; respectiv al neglijenţei profesionale grave (încălcarea diligenţei profesionale).

\section{Observaţii conclusive}

Următoarele observaţii conclusive pot fi desprinse pe marginea consideraţiilor de mai sus privitoare la exerciţiul dreptului consumatorului de rambursare anticipată; respectiv la sanç̧iunile aplicabile creditorului pentru nerespectarea unor obligaţii legale specifice:

(1) Ca urmare a exercitării dreptului de rambursare anticipată; consumatorul poate obţine o reducere a costului total al creditului; constând în dobânda şi costurile aferente perioadei dintre data rambursării anticipate şi data prevăzută pentru încetarea contractului de credit; creditorilor profesionişti nu le este permis să condiţioneze rambursarea anticipată de plata unei anumite sume minime sau de un anumit număr de rate achitate;

(2) Creditorilor profesionişti le este interzis să perceapă un comision de rambursare anticipată în următoarele situaţii: rambursarea anticipată a fost realizată ca urmare a executării unui contract de asigurare care are drept scop asigurarea riscului de neplată; contractul de credit este acordat sub forma facilităţii de overdraft/descoperit de cont; de asemenea; nu dă naştere unei obligaţii de plată a unei compensaţii rambursarea anticipată totală sau parţială a creditului care intervine într-o perioadă în care rata dobânzii aferente creditului nu este fixă; 
(3) Creditorul profesionist are obligaţia de a informa consumatorul încă din faza precontractuală asupra modalităţii de calcul al compensaţiei; modalitate care trebuie să fie clară; transparentă şi verificabilă pe baza unor elemente obiective;

(4) Limita maximă aplicabilă valorii compensaţiei de rambursare anticipată este cea rezultând din valoarea dobânzii pe care ar fi perceput-o creditorul în intervalul de timp pentru care are loc plata anticipată;

(5) Cuantumul compensaţiei de rambursare anticipată care poate fi practicată este de maxim $1 \%$ din valoarea rambursată anticipat; pentru creditele cu durată mai mare de 1 an şi; respectiv la 0;5\% din valoarea rambursată anticipat; pentru creditele contractate pentru o durată sub un an. Încălcarea acestor dispoziţii legale de către creditorul profesionist reprezintă contravenţie şi se sancţionează cu amenda contravenţională; respectiv cu obligarea creditorului la restituirea către consumator a sumelor percepute cu încălcarea dispoziţiilor legale imperative;

(6) Din dispoziţiile art. 80; alin. (1) din O.U.G. nr. 50/2010 privind contractele de credit încheiate cu consumatorii; cu modificările şi completările ulterioare aduse prin O.U.G. nr. 52/2016 privind contractele de credite oferite consumatorilor pentru bunuri imobile rezultă că clauzele de renunţare a consumatorului la drepturile conferite cu privire la rambursarea anticipată a creditului sunt lovite de nulitate;

(7) Ca sanç̧iune complementară; agentul constatator poate dispune aducerea contractului în conformitate cu prevederile legale; de către creditorul profesionist; în termen de maximum 15 zile; în cazul constatării unei contravenţii în forma introducerii în contractele de credit a unor clauze abuzive; cum ar fi clauza de renunţare a consumatorului la dreptul de rambursare anticipată; clauza de modificare unilaterală a contractului de către creditor fără încheierea unui act adiţional;

(8) Sanç̧iunea amenzii contravenţionale; precum şi sanç̧iunile complementare sunt aplicabile şi pentru încălcarea formalismului informativ; respectiv omiterea informaţiilor obligatorii din textul contractual privind modalitatea de calcul a compensaţiei pentru rambursare anticipată;

(9) În perspectiva domeniului de aplicare rationae materiae al dispoziţiilor privind obligaţia creditorilor profesionişti de transparenţă în ceea ce priveşte maniera de stabilire a cuantumului compensaţiei de rambursare anticipată; noţiunea de acţiune înşelătoare sau de omisiune înşelătoare; ca specii de practici comerciale neloiale; se pot materializa atât în omiterea de către creditorul profesionist; în faza precontractuală şi în momentul semnării contractului de credit; a informaţiilor privitoare la modalitatea obiectivă de calcul a valorii compensaţiei de rambursare anticipată (a); cât şi la acţiuni înşelătoare; cum ar fi utilizarea de formule de calcul netransparente; fondate pe elemente echivoce; în absenţa unor indicatori obiectivi de referinţă. 
* Lect. univ. dr., Facultatea de Drept, Universitatea „Babeş-Bolyai” Cluj-Napoca, jgoicovici@yahoo.com.

${ }^{1}$ A se consulta Z. Fungačova; L. Weill; „Does bank competition reduce cost of credit? Cross-country evidence from Europe”; în „Journal of Banking and Finance” vol. 83; nr. 3/2017; p. 104-120.

${ }^{2}$ A se consulta C. Noblot; „Droit de la consommation”; L.G.D.J.; Paris; 2012; p. 84.

${ }^{3}$ Publicată în M. Of. nr. 727 din 20 septembrie 2016.

${ }^{4}$ A se vedea J.-D. Pellier; „Droit de la consommation”; Dalloz; Paris; 2016; p. 118; Zhiyong Li; Xuao Yao; Qing Wen; Wei Yang; „Prepayment and Default of Consumers Loans in Online Lending”; postat în data de 01.03.2016; disponibil ca webografie la adresa https://ssrn.com/abstract=2740858; consultată în data 12.11.2017.

${ }^{5}$ A se consulta J. Julien; „Droit de la consommation”; L.G.D.J.; Paris; 2017; p. 241; S. le Gac-Pech; „Droit de la consommation"; Dalloz; Paris; 2017; p. 132.

${ }^{6}$ A se consulta pentru detalii J. Calais-Auloy; Fr. Steinmetz; „Droit de la consommation”; 5e édition; Dalloz; Paris; 2008; p. 185-208 ; Y. Picod; H. Davo; „Droit de la consommation”; Ed. Armand Colin; Paris; 2008; p. 139-156; S. Piedelièvre; „Droit de la consommation”; Economica; Paris; 2010; p. 342368; T. Vignal; "Réflexions sur le crédit immobilier en droit international privé”; în "Mélanges M. Cabrillac"; Ed. Litec; Paris; 1999; p. 545 şi urm.; F. Capriglione; „Operazioni bancarie e tipologia contrattuale”; în „Rivista di diritto civile” nr. 1/2006; Dottrina; p. 26-54; M. Aden; „Comentariu (Aç̧iunea în despăgubiri a clienţilor pentru consiliere eronată din partea agenţilor băncii)"; Conferinţa internaţională "Probleme actuale în domeniul juridic bancar"; în volumul „Probleme actuale în dreptul bancar//Current Issues in Banking Law”; Ed. Wolters Kluwer; Bucureşti; 2008; C.D. Enache; "Clauzele abuzive în contractele încheiate între profesionişti şi consumatori; Practică judiciară"; Ed. Hamangiu; Bucureşti; 2012; p. 76 şi urm.; E. Beguin; C. Biquet-Mathieu; „Le crédit hypothécaire au consommateur"; Larcier; Bruxelles; 2017; p. 76-88; C. Biquet-Mathieu; "Crédit aux consommateurs et aux P.M.E.”; Larcier; Bruxelles; 2016; p. 112-118.

7 Pentru detalii; a se consulta Y. Picod; „Droit de la consommation”; Editions Sirey; Paris; 2015; p. 187.

${ }^{8}$ A se consulta; pentru exemplificarea caracterului disproporţionat al compensaţiei; astfel cum a fost acesta reflectat în practica judiciară; V. Terzea; „Protecţia consumatorilor. Jurisprudenţa Curţii de Justiţie a Uniunii Europene"; Universul Juridic; Bucureşti; 2016; p. 139-141.

${ }^{9}$ A se vedea S. Piedelièvre; „Droit de la consommation”; cit. supra; p. 127.

${ }^{10}$ A se consulta J. Calais;-Auloy; H. Temple; „Droit de la consommation”; 9e édition; Dalloz; Paris; 2015; p. 233.

${ }^{11}$ A se vedea Y. Picod; „Droit de la consommation”; cit. supra; p. 192.

${ }^{12}$ A se consulta T. Bonneau; „Droit bancaire”; L.G.D.J.; Paris; 2017; p. 311; F. Dekeuwer-Défossez; S. Moreil; „Droit bancaire”; Dalloz; Paris; 2016; p. 298.

${ }^{13}$ Facilitatea de credit sau descoperitul de cont este definit(ă) în art. 2193 din noul Cod civil ca fiind contractul prin care o instituţie de credit; o instituţie financiară nebancară sau o altă entitate autorizată pentru prestarea de servicii financiare se obligă să menţină la dispoziţia debitorului o sumă de bani; în limita unui anumit plafon; pentru o perioadă de timp determinată sau nedeterminată. în ceea ce priveşte utilizarea creditului; din cuprinsul art. 2194 rezultă că debitorul poate să utilizeze creditul în mai multe tranşe; respectiv poate; prin rambursări succesive; să reînnoiască suma disponibilă.

14 Pentru detalii; a se consulta G. Biardeaux; P. Flores; „Crédit à la consommation”; Editions Delmas; Paris; 2012; p. 251. 
${ }^{15}$ A se vedea M. Djurovic; N. Lazarevic; „The new Serbian law on consumer protection and the position of Serbian consumer"; în "Robert Schuman Centre for Advanced Studies; The 13th Mediterranean Research Meeting; Workshop 11; Political Governance and Regulatory Enforcement Activity in Competition and Consumer Protection Regulation"; 2012; p. 25-28.

${ }^{16}$ A se vedea G. Raymond; „Droit de la consommation”; LexisNexis; Paris; 2017; p. 211.

17 Reamintim faptul că nulitatea clauzelor bancare abuzive este; de regulă; o nulitate parţială; afectând doar clauza în sine; care va fi reputată ca nescrisă sau extirpată din câmpul contractual; raporturile contractuale urmând să se deruleze în continuare; în măsura în care nu este afectată însăşi cauza acestora.

${ }^{18}$ CJUE; camera a şasea; hotărârea din 19 dec. 2013; C-281/12; publicată în ECLI:EU:B:2013:859; citată după V. Terzea; „Protecţia consumatorilor. Jurisprudenţa Curţii de Justiţie a Uniunii Europene”; cit. supra; p. 451-453.

19 Transpusă în dreptul naţional prin Legea nr. 363/2007 privind combaterea practicilor incorecte ale comercianţilor în relaţia cu consumatorii şi armonizarea reglementărilor cu legislaţia europeană privind protecţia consumatorilor; cu modificările şi completările aduse prin O.G. nr. 37/2015 pentru modificarea unor acte normative din domeniul protecţiei consumatorilor; aprobată cu modificări prin Legea nr. 51/2016 pentru aprobarea O.G. nr. 37/2015 pentru modificarea unor acte normative din domeniul protecţiei consumatorilor; publicată în M. Of. nr. 257 din 6 aprilie 2016.

${ }^{20}$ După cum s-a menţionat în literatura de specialitate; practicile comerciale susceptibile să deformeze în mod esenţial comportamentul economic al unui anumit grup vulnerabil de consumatori; clar identificabil; trebuie evaluate din perspectiva membrului mediu al grupului de consumatori; a se vedea G. Raymond; „Droit de la consommation”; cit. supra; p. 78. Astfel cum a argumentat profesorul Guy Raymond; deformarea substanţială a comportamentului economic al consumatorilor implică utilizarea unui criteriu subiectiv; centrat pe consumator; un criteriu utilizabil pentru identificarea existenţei unei practici neloiale. Respectivul criteriu se referă la folosirea de către profesionist unei practici comerciale cu scopul de a afecta în mod considerabil capacitatea consumatorilor de a lua o decizie în cunoştinţă de cauză; determinându-i astfel să ia o decizie pe care nu ar fi luat-o. în materia împrumutului de consum; este vorba despre elementul subiectiv al consimţământului avizat al consumatorului la momentul încheierii contractului ori la momentul convenirii unui act adiţional la contractul de credit.

21 De asemenea; reprezintă contravenţii; sancţionate cu amenda contravenţională; încălcarea dispoziţiilor legale imperative privind: (1) încetarea contractelor de credit pe durată nedeterminată art. 54; exigenţele aplicabile exerciţiului dreptului pe care îl are creditorul profesionist de a suspenda posibilitatea consumatorului de a efectua trageri în baza contractului de credit pe durată nedeterminată - art. 55 din O.U.G. nr. 50/2010; (2) dispoziţiile legale privitoare la obligaţia de informare specifică descoperitului de cont cu aprobare tacită; inclusiv asupra depăşirii semnificative a limitei de credit; (3) prevederile legale referitoare la dreptul consumatorului de retragere din contractul de credit; în termen de 14 zile calendaristice; fără a invoca motive; termenul de retragere începând să curgă fie de la data încheierii contractului de credit; fie de la data la care consumatorului îi sunt aduse la cunoştinţă clauzele; condiţiile contractuale şi informaţiile potrivit prevederilor art. 33-49; în cazul în care ziua respectivă este ulterioară datei semnării contractului; (4) prevederile legale privitoare la interzicerea anumitor comisioane bancare - art. 34 din O.U.G. nr. 50/2010; 
conform căruia pentru creditul acordat; creditorul poate percepe numai: comision de analiză dosar; comision de administrare credit sau comision de administrare cont curent; compensaţie în cazul rambursării anticipate; costuri aferente asigurărilor şi; după caz; dobânda penalizatoare; alte costuri percepute de terţi; precum şi un comision unic pentru servicii prestate la cererea consumatorilor; comisionul de analiză dosar şi cel unic vor fi stabilite în sumă fixă; aceeaşi sumă fiind percepută tuturor consumatorilor cu acelaşi tip de credit în cadrul aceleiaşi instituţii de credit.

22 Dispoziţiile legale citate interzic totodată perceperea unui comision de depunere numerar pentru plata ratelor la credit; indiferent dacă depunerea se efectuează de către titular sau de către o altă persoană (a); perceperea unui comision de retragere pentru sumele trase din credit; se interzice perceperea unui comision; unui tarif; unei speze bancare sau a oricărui alt cost; în cazul în care consumatorul doreşte schimbarea datei de scadenţă a ratelor (b); perceperea unor comisioane în situaţiile în care consumatorii solicită schimbarea garanţiilor; în condiţiile în care consumatorul plăteşte toate costurile aferente constituirii şi evaluării noilor garanţii (c). Pentru orice modificare a nivelului costurilor creditului; potrivit condiţiilor contractuale; creditorul este obligat să notifice consumatorul în scris sau; la cererea expresă a consumatorului; prin altă modalitate stabilită de acesta şi agreată de creditor şi va pune la dispoziţia acestuia un nou tabel de amortizare/grafic de rambursare.

${ }^{23}$ Nerespectarea de către creditorul profesionist a dispoziţiilor privitoare la exercitarea dreptului de retragere din contract; conform căruia exercitarea dreptului de retragere îşi produce efectul de la data expedierii notificării de către consumator reprezintă contravenţie; de asemenea; reprezintă contravenţie încălcarea dispoziţiilor art. 60; conform căruia creditorul nu poate percepe un comision autonom pentru exercitarea dreptului consumatorului de retragere din contract în intervalul de 14 zile calendaristice de la semnare; principiul potrivit căruia încetarea raporturilor contractuale de creditare ca urmare a retragerii consumatorului din contractul de credit în termen de 14 zile calendaristice de la semnarea lui atrage încetarea oricăror raporturi contractuale accesorii - art. 61; prevederile legale referitoare la dreptul de retragere în cazul creditelor legate - art. 63 din O.U.G. nr. 50/2010; (a) dispoziţiile art. 65; conform căruia în cazul în care bunurile sau serviciile care fac obiectul unui contract de credit legat nu sunt furnizate sau sunt furnizate numai în parte sau nu sunt conforme cu contractul de furnizare; consumatorul are dreptul de a se îndrepta împotriva creditorului în cazul în care nu a reuşit să obţină; de la furnizor; satisfacerea pretenţiilor la care are dreptul în conformitate cu legislaţia sau cu contractul de furnizare a bunurilor sau a serviciilor; (b) dispoziţiile legale imperative privitoare la dreptul consumatorului de rambursare anticipată - art. 6669; (c) prevederile legale referitoare la cesiunea de drepturi - art. 70-71 din ordonanţa de urgenţă citată; (d) exigenţele legale imperative referitoare la DAE - dobânda anuală efectivă (art. 72-76); (e) prevederile legale referitoare la obligaţiile intermediarilor de credite faţă de consumatori - art. 7778; (f) dispoziţiile art. 84 privitoare la raporturile de drept internaţional privat; conform cărora consumatorii nu pierd protecţia acordată în baza OUG nr. 50/2010; în cazul în care se stabileşte ca lege aplicabilă contractului legea unui stat care nu este membru U.E.; în cazul în care contractul de credit are o strânsă legătură cu teritoriul unuia sau al mai multor state membre.

24 Reamintim că; în cazul acuzaţiilor de inexactitate; sarcina probei incumbă comercianţilor/ profesioniştilor; care trebuie să furnizeze dovezi privind corectitudinea afirmaţiilor în legătură cu practica comercială întreprinsă şi care sunt obligaţi; la solicitarea ANPC ori a instanţelor de judecată; să le pună acestora la dispoziţie documente care să probeze cele afirmate în mesajele publicitare. 
${ }^{25}$ T. Bonneau; „Droit bancaire”; cit. supra; p. 312. A se vedea; de asemenea; F. Dekeuwer-Défossez; S. Moreil; „Droit bancaire”; cit. supra; p. 192.

${ }^{26}$ A se consulta C. Biquet-Mathieu; „Crédit aux consommateurs et aux P.M.E.”; cit. supra; p. 133-134.

${ }^{27}$ Publicată în M. Of. nr. 257 din 6 aprilie 2016.

${ }^{28}$ A se vedea E. Beguin; C. Biquet-Mathieu; „Le crédit hypothécaire au consommateur”; cit. supra; $\mathrm{p}$. 119. 